\title{
IEEJ Journal of Industry Applications Vol.9, No.3 \\ Special Issue on "SPC-Power Electronics and Its Applications"
}

$$
\text { ゲストエディタ 伊東 淳一 (長岡技術科学大学) }
$$

IEEJ Journal of Industry Applications（電気学会英文論文誌 D）では，Vol.9 No.3「Special Issue on “SPC-Power Electronics and Its Applications”」特集号を発行いたします。電気学会産業応用部門論文委員会と半導体電力変換技術委員会（SPC）では，部門和 文論文誌ならびに部門英文論文誌の活性化を目的として，令和 2 年 5 月号に SPC 特集号を企画していました。産業応用部門和 文論文委員会と産業応用部門英文論文委員会と半導体電力变換技術委員会の 3 つ委員会で, 企画するものです。英文論文誌で の“SPC-Power Electronics and Its Applications”の特集号は，韓国，中国，台湾を初めとする著名な先生方を中心に，ゲストエディ タが直接，呼びかけて論文投稿していただきました。本特集号は，その中から電気学会の查読プロセスで厳正に採否が決定さ れた論文のみを掲載しています。ぜひ世界第一線の技術レベルと技術潮流を感じていただきたいと思います。最後に，特集号 を発行するにあたり，論文を投稿いただいた著者の皆様，査読にご尽力をいただきました皆様に感謝の意を表します。

なお，英文論文誌 IEEJ Journal of Industry Applications は， Elsevier 社が運営するデータベース Scopus の EI-Compendex 2017 年 5 月に登録されました。また, Clarivate Analytics 社（2016 年 Thomson Reuter 社から分離）が運営している学術文献データベ ースの Web of Science のデータベースの Emerging Sources Citation Index (ESCI)に，2016 年 11 月に登録されました。

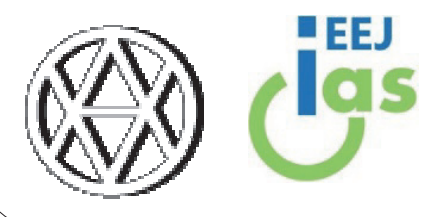

Web of Science Trust the difference

\section{Scopus ${ }^{\circ}$ j compendex}

が盛り沢山な内容となっております。産業応用フォーラムは 最新の技術動向や実際の現場を見学できる貴重な機会と存 じますので，奮ってのご応募をお願い申し上げます。

また, 今月号の国際会議レポートでは, シンガポールで開 催された IFEEC 2019 についてのご報告がございました。こ れまでは台湾で開催されていたそうですが, 今回初めて台湾 以外で開催されたそうです。

この他にも, 今月号も様々な情報が掲載されておりますの で，まだの方は是非開いてご一読ください。

最後に, 記事のご執筆者の皆様, 編集作業に携わっていた だきました皆様に, 本紙面をお借りしまして厚く御礼申し上 げます。誠に有難うございました。

$$
\text { エディタ 長津 裕己（中央大学） }
$$

※本文中の E-mail アドレスをご利用になる場合は，”(at)” を”@”に置き換えてください。

\section{主な記事}

・表紙 : 産業応用フォーラム

おかれましても, 新型ウイルスにかかわらず体調を崩されま せんようご自愛ください。

さて, 今月号の巻頭には, 第六期モー夕道場長の開催案内 記事が掲載されております。

今月号はその他複数の産業応用フォーラムに関する記事
「第六期モー夕道場」開催案内

・産業応用フォーラム「初心者向け技術講習会」開催案内

・産業応用フォーラム「第五期モー夕道場」を終えて

- 産業応用フォーラム報告

・国際会議レポート(IFEEC2019) 